\title{
PERKEMBANGAN TANAH DARI BAHAN INDUK VULKANIK DI DESA CILELES, KECAMATAN JATINANGOR
}

\section{DEVELOPMENT OF SOIL FROM VOLCANIC PARENT MATERIAL IN CILELES VILLAGE, JATINANGOR DISTRICT}

\author{
Ganjar Herdiansyah $^{1 \text { ()) }}$,Emma Trinurani Sofyan ${ }^{2)}$, Saedi Bawana ${ }^{2)}$ dan Aktavia \\ Herawati ${ }^{1)}$ \\ ${ }^{1)}$ Prodi Ilmu Tanah, Fakultas Pertanian, Universitas Sebelas Maret \\ ${ }^{2)}$ Departemen Ilmu Tanah dan Sumberdaya lahan Fakultas Pertanian, Universitas \\ Padjadjaran \\ ${ }^{*}$ Corresponding author E - mail: ganjarh@staff.uns.ac.id
}

\begin{abstract}
The process of soil formation and development in the research location is the first step to identify in an effort to obtain information on soil characteristics. Agricultural land development requires basic information about the soil by knowing all the properties or characteristics of the soil. The purpose of this study was to determine the process of soil development that developed from volcanic parent material. The research was conducted using descriptive and survey methods. Soil observations were made by making a soil profile. The results show that the soil in Cileles developed from basaltic volcanic material which shows lithologic discontinuity, the level of soil development takes place at the viril or cambic stage and soil classification according to soil taxonomy 2014, sub group category, namely Fluventic Humudepts.
\end{abstract}

Keywords: Soil development, volcanic parent material, lithologic discontinuity, fluventic humudepts

\begin{abstract}
ABSTRAK
Proses pembentukan dan perkembangan tanah di lokasi penelitian merupakan langkah awal untuk diketahui dalam upaya mendapatkan informasi karakteristik tanah. Pengembangan lahan pertanian memerlukan informasi dasar tentang tanah dengan mengetahui semua sifat atau karakteristik tanah tersebut. Tujuan dari penelitian ini adalah untuk mengetahui proses perkembangan tanah yang berkembang dari bahan induk vulkanik. Penelitian dilakukan dengan metode deskriptif dan survei, pengamatan tanah dilakukan dengan pembuatan profil tanah. Hasil penelitian menunjukkan tanah di Cileles berkembang dari bahan volkan basaltik yang menunjukkan adanya ketidaksinambungan litologi (lithologic discontinuity), tingkat perkembangan tanah berlangsung pada tahap viril atau kambik dan klasifikasi tanah menurut soil taxonomy 2014 kategori sub group yaitu Fluventic Humudepts.
\end{abstract}

Kata Kunci: Perkembangan Tanah, Bahan Induk Vulkanik, lithologic discontinuity, fluventic humudepts 


\section{PENDAHULUAN}

Proses pembentukan tanah dipengaruhi oleh lima faktor yang saling bekerja sama secara fisika dan kimia dalam berbagai proses untuk membentuk tanah. Faktor pembentuk tanah tersebut adalah iklim, organisme, bahan induk, relief dan waktu (Jenny, 1941). Proses pembentukan tanah ini akan menghasilkan karakteristik tanah yang berbeda baik sifat kimia, fisika dan biologi. Menurut Hardjowigeno, (1993) dalam proses pembentukan dan perkembangan tanah memerlukan waktu untuk menghasilkan jenis tanah serta karakteristik yang berbeda sesuai dengan kondisi faktor pembentukannya.

Perbedaan jenis dan karakteristik tanah ini perlu dilakukan penggolongan untuk memudahkan dalam menentukan tingkat pengelolaannya. Salah satu upayanya adalah dengan klasifikasi tanah. Klasifikasi tanah ini sangat perlu dilakukan guna mempelajari sifat-sifat tanah dan mengelompokkan tanah kedalam kelas tertentu berdasarkan dari kesamaan sifat yang dimilikinya (Hardjowigeno, 2003). Keterkaitan antara tanah dan tanaman dapat dilihat dari tujuan klasifikasi tanah yaitu untuk mengetahui susunan atau aturan mengenai tanah dan hubungannya dengan tanaman, baik dari segi produksi maupun kesuburan tanahnya (Panjaitan et al., 2015).

Sistem klasifikasi tanah yang berkembang di Indonesia pada saat ini adalah sistem klasifikasi soil taxonomi (USDA), sistem klasifikasi WRB/FAO dan sistem klasifikasi tanah nasional yang berupa juknis dalam klasifikasi tanah. Semua sistem klasifikasi ini memiliki prosedur yang sama dalam menentukan suatu jenis tanah, pada dasarnya sistem klasifikasi merujuk pada karakteristik atau sifat tanah tersebut.

Secara geologi desa Cileles termasuk kedalam Formasi Geologi Qyu (Quarter young unidentified) yang berumur plistosen (Arifin et al., 2017). Geologi Qyu ini hasil dari gunung api muda tak teruraikan yang bersifat andesitik-basaltik. Formasi geologi ini berasal dari letusan Gunung Tangkuban Perahu dan sebagian dari Gunung Tampomas. Satuan gunung api muda takteruraikan (Qyu) memiliki litologi berupa pasir tufaan, lapili, breksi, lava dan aglomerat (Rukmana et al., 2020). Landform lokasi penelitian merupakan lungur volkan bawah dengan relief bergelombang pada kemiringan lereng $8-15 \%$.

Pengembangan sektor pertanian di lokasi penelitian sangat potensial, terutama pertanian lahan kering dengan komoditas tanaman pangan. Sebagai langkah awal diperlukan data base atau informasi awal berupa karakteristik tanah untuk dijadikan pedoman dan arahan pengembangan pertanian. Pengetahuan tentang perkembangan tanah di lokasi penelitian menjadi sangat penting guna mendapatkan dan mengetahui karakteristik tanah tersebut.

\section{METODE PENELITIAN}

Pengamatan tanah dilakukan di Desa Cileles, Kecamatan Jatinangor, Kabupaten Sumedang, Jawa Barat yang terletak pada $6^{\circ} 55^{\prime} 21,01^{\prime \prime L S}$ dan $107^{\circ} 46^{\prime} 27,25^{\prime \prime}$ BT dengan ketinggian tempat $751 \mathrm{~m}$ dpl. Lokasi penelitian pada Gambar 1.

Analisis laboratorium dilakukan di Laboratorium Kesuburan Tanah dan Nutrisi Tanaman serta Laboratorium Fisika Tanah, Departemen Ilmu Tanah dan Sumberdaya Lahan, Fakultas Pertanian, Universitas Padjadjaran. 


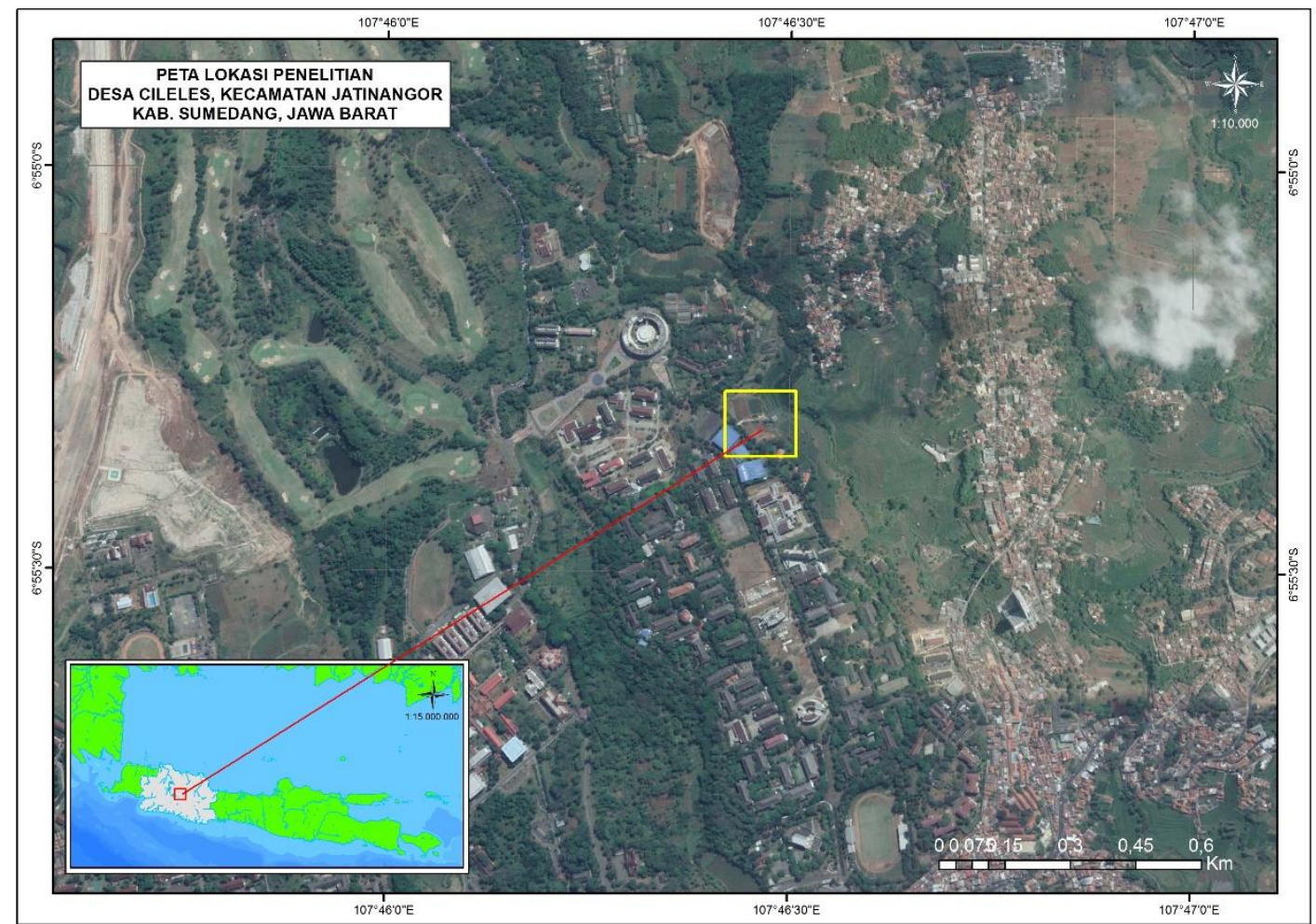

Gambar 1. Lokasi Penelitian

Penelitian dilakukan dengan metode deskriptif dan survei. Lokasi pengamatan tanah ditentukan melalui survei lapangan terlebih dahulu untuk menentukan ordo tanah dengan bantuan Peta Tanah Jawa Barat skala 1:250.000, Peta Geologi Lembar Bandung skala 1:250.000 dan Peta Rupa Bumi Indonesia skala 1:25.000. Penetapan jenis tanah didasarkan pada karakteristik tanah (Soil Survey Staff, 2014) dan (Rachim dan Arifin, 2011) melalui pembuatan profil tanah.

Deskripsi profil tanah berpedoman pada buku panduan Soil Taxonomy tahun 2014. Pengamatan yang dilakukan meliputi Morfologi tanah diantaranya warna tanah, tekstur, struktur, batas horison, konsistensi, pori-pori, akar, karatan dan pengamatan lingkungan diantaranya lereng, batuan, landform, penggunaan lahan, erosi dan drainase.

\section{HASIL DAN PEMBAHASAN}

\section{Sifat Morfologi Tanah}

Tanah hasil pengamatan yang berasal dari batuan vulkanik dicirikan oleh penampang tanah dalam dengan kedalaman $>150 \mathrm{~cm}$ (Gambar 2). Tanah tersebut menunjukkan 7 horison tanah, yang dapat dibedakan menjadi 2 sekum/timbunan bahan yang berbeda, artinya di lokasi penelitian terjadi lithologic discontinuity. Ketidaksinambungan litologi merupakan perubahan signifikan dalam berbagai hal seperti warna, ukuran partikel serta mineralogi yang mewakili perbedaan litologis dalam profil tanah (Ahr et al., 2017). Timbunan pertama yaitu sampai kedalaman 80 $\mathrm{cm}$ terdiri dari 5 horison yaitu Ap1, Ap2, Ap3, AB dan Bw. Sedangkan timbunan 
kedua pada kedalaman 80-150 cm yang terdiri dari horison 2BA dan $2 \mathrm{Bw}$. Terjadi proses perkembangan tanah yang berbeda pada setiap sekumnya. Perkembangan tanah pada setiap sekum ini merupakan ciri bahwa selang waktu penimbunan bahan vulkanik (umur erupsi) cukup lama (Arifin et al., 2017).

Sifat morfologi tanah yang diamati diantaranya adalah warna tanah. Warna tanah dalam kondisi lembab menunjukkan coklat gelap (10 YR 3/3), coklap gelap kekuningan (10 YR 3/6) sampai coklat (7,5 YR 4/6) pada kedalaman 0-80 cm. Warna tanah pada kedalaman $80-150 \mathrm{~cm}$ berkisar warna coklat terang $(7,5 \mathrm{YR} 5 / 6)$ sampai merah kekuningan (5YR 4/6). Hasil ini menunjukkan adanya perbedaan dari sekum pertama dengan yang kedua, dimana pada sekum pertama warna tanah lebih gelap/tua sedangkan sekum kedua lebih terang dan bahkan kemerahan. Kaitan warna tanah pada setiap sekum dengan sifat dan umur bahan induk tidak memperlihatkan perbedaan warna yang mencolok, hal ini karena ada pengaruh dari bahan induk basaltik dengan curah hujan yang tinggi. Menurut Arifin et al., (2017), keadaan ini diduga sifat bahan induk basaltik pada kondisi curah hujan yang tinggi di lokasi penelitian menyebabkan warna tanah cenderung coklat gelap kekuningan.

Pengamatan sifat morfologi lainnya seperti konsistensi, struktur menunjukkan adanya perkembangan, walaupun belum mencapai tingkat perkembangan lanjut. Konsistensi didominasi oleh konsistensi teguh sedangkan pada permukaan tanah memiliki konsistensi gembur. Hal ini karena adanya pengolahan tanah, yang mana lokasi penelitian merupakan lahan ladang yang ditanami tanaman jagung. Bentuk struktur dari sub angular blocky (sbk) sampai angular blocky (abk), tingkat kemantapan agregatnya menunjukkan pada tingkatan lemah sampai cukup, artinya bahwa tanah tersebut merupakan tanah yang berkembang. Tingkat perkembangan struktur tanah ditentukan berdasarkan kemantapan bentuk struktur tersebut terhadap tekanan (Meli et al., 2018). Sifat morfologi tanah yang diamati di lapangan, terdapat pada Tabel 1.

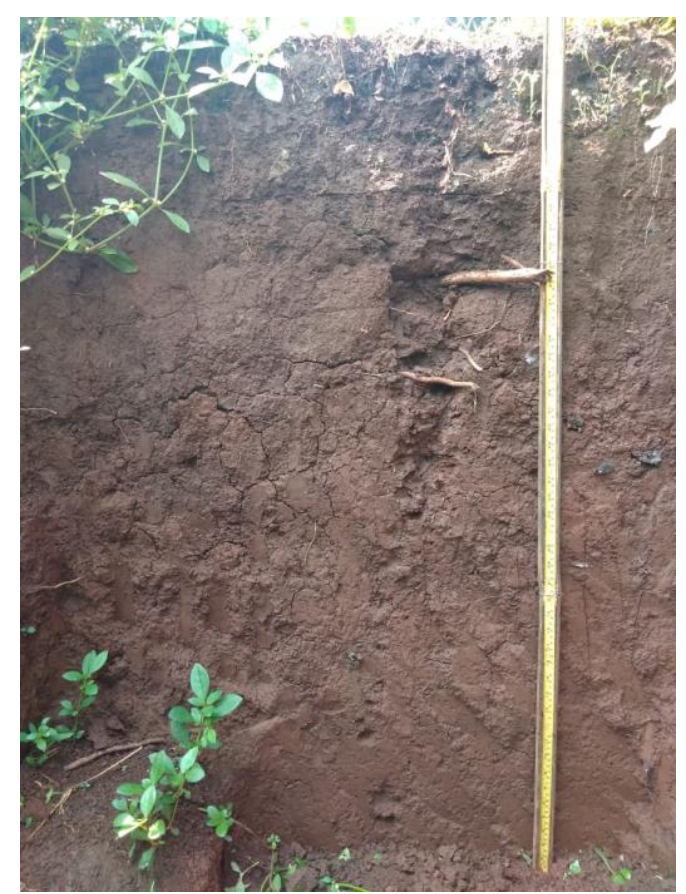

Gambar 2. Profil Tanah di Lokasi Penelitian 


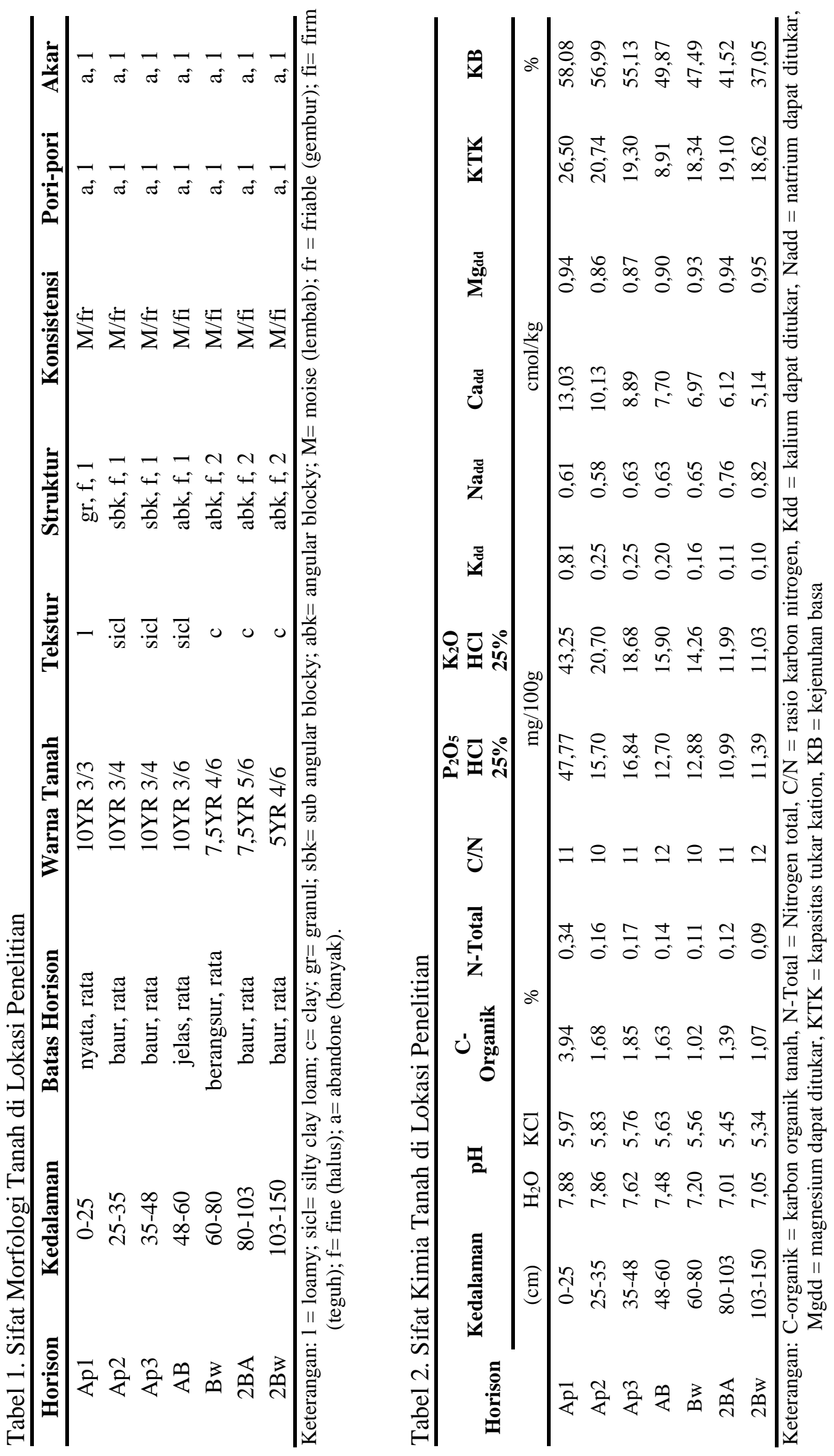




\section{Sifat Kimia Tanah}

Pengamatan terhadap sifat kimia tanah di lokasi penelitian menunjukkan tingkat kemasaman tanah $\left(\mathrm{pH} \mathrm{H}_{2} \mathrm{O}\right)$ berada pada kisaran 7,88-7,01 yaitu agak alkalis sampai netral. Semakin dalam kedalaman tanah maka kemasaman tanah akan menjadi lebih netral. $\mathrm{pH}$ yang tinggi ini akibat dari pengaruh bahan induk yang bersifat basaltik, tanah ini memperlihatkan pengaruh dari bahan induk lebih dominan dibandingkan dengan faktor pembentuk tanah lain. pengaruh bahan induk akan mudah terlihat pada tanah-tanah yang baru berkembang. Batuan basaltik merupakan batuan volkan yang bersifat netral sampai alkalis, pelapukan batuan ini menghasilkan tanah-tanah yang subur (Aji dan Teapon, 2019). Hasil pengamatan sifat kimia tanah pada Tabel 2.

Nilai C-organik berkisar antara 3,94-1,02\%. Tingginya C-organik pada horison Ap menunjukkan adanya akumulasi bahan organik yang tinggi pada horison permukaan. Seiring bertambahnya kedalaman nilai C-organik menurun. Namun pada kedalaman 80-103 atau pada horison 2 BA terdapat peningkatan kembali nilai C-organik dari $1,02 \%$ menjadi $1,39 \%$. Hal ini menunjukkan adanya peningkatan $\mathrm{C}$ organik yang tidak lazim, kecuali adanya ketidaksinambungan litologi. Peningkatan kembali C-organik pada horison yang cukup jauh dengan tidak lazim, menunjukkan horison yang sudah berkembang sebelumnya atau horison yang tertimbun (Devnita et al., 2018).

Hasil analisis Kapasitas Tukar Kation (KTK) berkisar antara 26,50-8,91 $\mathrm{cmol} / \mathrm{kg}$ yaitu tinggi sampai sedang. Pada horison Ap memiliki nilai KTK tinggi, hal ini karena dipengaruhi oleh bahan organik yang tinggi. Senada dengan penelitian N Suharta, (2007) tanah dengan jenis mineral liat sama, nilai KTK sangat bergantung pada kandungan bahan organik. Hasil pengamatan menunjukkan seiring bertambahnya kedalaman tanah nilai KTK semakin kecil, namun pada horison 2BA terjadi kenaikan dari $18,34 \mathrm{cmol} / \mathrm{kg}$ menjadi $19,10 \mathrm{cmol} / \mathrm{kg}$. Nilai KTK pada horison 2BA naik karena dipengaruhi oleh nilai C-organik yang naik pula. Nilai kejenuhan basa berkisar antara 58,08-37,05\% yaitu sedang sampai rendah. Seiring bertambahnya kedalaman nilai kejenuhan basa semakin rendah. Nilai kejenuhan basa menunjukkan tingkat kesuburan tanah, namun nilai $\mathrm{KB}$ tinggi harus dicermati kembali, karena kejenuhan basa ini berhubungan dengan kapasitas tukar kation dan kandungan mineral sekunder yang mendominasinya.

\section{Sifat Fisika Tanah}

Tekstur (Tabel 3) di lokasi penelitian menunjukkan kelas tekstur lempung berdebu, lempung liat berdebu sampai liat. Fraksi pasir lebih sedikit dibandingkan dengan fraksi debu dan liat. Fraksi pasir dan fraksi liat semakin bertambahnya kedalaman semakin menurun dan fraksi liat semakin bertambahnya kedalaman semakin meningkat. Hal ini karena terjadi proses perkembangan tanah yang masih berlangsung. Dalam proses perkembangan pasir dan debu akan melapuk menjadi fraksi yang lebih halus. Dengan ini maka pedon yang diteliti memperlihatkan proses pelapukan yang lebih intensif pada bagian lapisan bawah dibandingkan lapisan atasnya. 
Tabel 3. Sifat Fisika Tanah di Lokasi Penelitian

\begin{tabular}{cccccc}
\hline Horison & Kedalaman & Pasir & Debu & Liat & Tekstur \\
\hline Ap1 & $0-25$ & 22,00 & 55,00 & 23,00 & lempung berdebu \\
Ap2 & $25-35$ & 15,00 & 47,00 & 38,00 & lempung liat berdebu \\
Ap3 & $35-48$ & 10,00 & 50,00 & 40,00 & lempung liat berdebu \\
AB & $48-60$ & 8,00 & 53,00 & 39,00 & lempung liat berdebu \\
Bw & $60-80$ & 5,00 & 40,00 & 55,00 & liat \\
2BA & $80-103$ & 5,00 & 37,00 & 58,00 & liat \\
2Bw & $103-150$ & 4,00 & 28,00 & 68,00 & liat \\
\hline
\end{tabular}

Kandungan liat lebih dominan dibandingkan dengan kandungan debu dan pasir, walaupun terjadi peningkatan liat namun terbentuknya horison argilik belum terpenuhi. Pada sekum pertama didominasi oleh fraksi debu sedangkan pada sekum kedua didominasi oleh fraksi liat, artinya sekum kedua memiliki perkembangan tanah lebih lanjut dibandingkan pada sekum pertama.

\section{Proses Perkembangan Tanah}

Tingkat perkembangan tanah yang terjadi pada Pedon di Lokasi penelitian termasuk pada tahap viril atau tahap kambik. Menurut Arifin et al., (2017) tahap kambik yaitu terbentuknya horison bawah B-kambik (Bw). Tahap viril ini dicirikan dengan kandungan liat telah meningkat tetapi tidak memenuhi terbentuknya argilik. Menurut Mohr et al., (1975) tahap virile pada perkembangan tanah yaitu dimana mineral-mineral mudah lapuk sebagian besar telah mengalami dekomposisi serta kandungan liat telah meningkat (tanah dewasa). Horison kambik yang ditemukan pada tanah ini merupakan alterasi bahan induk volkanik dimana penimbunan (iluviasi) dari bahan tanah hasil pencucian pada horison diatasnya belum memenuhi syarat untuk terbentuknya horison argilik atau kandik. Berdasarkan penilaian warna tanah pada horison kambik memiliki warna tanah lebih terang jika dibandingkan dengan horison diatasnya (horison A). Adanya ketidaksinambungan litologi (lithologic discontinuity) mengakibatkan proses pembentukan tanah menjadi terhambat akibat dari penimbunan bahan volkan yang terjadi berulang-ulang dari erupsi yang berbeda umurnya sehingga tanah ini berumur dewasa. Hasil penelitian Arifin et al., (2017) bahwa pedon Jatinangor didominasi oleh mineral liat kaolinit, hal ini membuktikan bahwa pedon tersebut mengalami pelapukan yang telah berlangsung lanjut.

\section{Klasifikasi Tanah}

Berdasarkan penelusuran sistem klasifikasi soil Taxonomy 2014 (Soil Survey Staff, 2014), tanah di lokasi penelitian termasuk pada kategori sub group yaitu Fluventic Humudepts. Horison atas dan bawah penciri yang ditemukan adalah horison kambik dan epipedon molik. Epipedon molik dicirikan dengan ketebalan horison $25 \mathrm{~cm}$ dengan warna tanah gelap (memiliki value dan chroma $\leq 3$ ), kandungan C-organik $\geq 2,5 \%$ dan kejenuhan basa 58,08\% ( $\geq 50 \%)$. Tanah ini memiliki kandungan C-organik lebih dari 0,2\% pada setiap kedalaman sampai 125 $\mathrm{cm}$ dari permukaan tanah dan terdapat penurunan secara tidak beraturan kandungan C-organik antara $25 \mathrm{~cm}$ sampai dengan $125 \mathrm{~cm}$. Hasil klasifikasi ini didasarkan dari karakteristik tanah yang diamati dilapangan dan dianalisis di laboratorium. 


\section{KESIMPULAN}

Tanah di Cileles berkembang dari bahan volkan basaltik dari dua stratifikasi bahan yang berbeda umur dengan adanya ketidaksinambungan litologi (lithologic discontinuity). Tingkat perkembangan tanah di lokasi penelitian berlangsung pada tahap viril atau kambik, ditandai dengan adanya alterasi bahan induk pada horison B. Klasifikasi tanah menurut soil taxonomy 2014 kategori sub group yaitu Fluventic Humudepts.

\section{DAFTAR PUSTAKA}

Ahr, S. W., Nordt, L. C., dan Schaetzl, R. J. 2017. Lithologic Discontinuities in Soils. In International Encyclopedia of Geography: People, the Earth, Environment and Technology. https://doi.org/10.1002/9781118786352.wbieg0816

Aji, H. B., dan Teapon, A. 2019. Pengaruh Batuan Induk dan Kimia Tanah terhadap Potensi Kesuburan Tanah di Kabupaten Kepulauan Sula, Provinsi Maluku Utara. Jurnal Pengkajian dan Pengembangan Teknologi Pertanian, 223, 343-353.

Arifin, M., Devnita, R., Hudaya, R., Sandrawati, A., Saribun, D. S., Harryanto, R., dan Herdiansyah, G. 2017. Pedogenesis Dan Klasifikasi Tanah Yang Berkembang Dari Dua Formasi Geologi Dan Umur Bahan Erupsi Gunung Tangkuban Perahu. SoilREns, 151, 20-28. https://doi.org/10.24198/soilrens.v15i1.13341

Devnita, R., Arifin, M., Hudaya, R., Sandrawati, A., dan Setiawan, A. 2018. Ketidaksinambungan Litologi dan Karakteristik Pedogenetik pada Beberapa Andisols di Jawa Barat. Soilrens, 162, 37-44.

Hardjowigeno, S. 1993. Klasifikasi Tanah dan Pedogenesis. Akademika Pressindo: Jakarta.

S. 2003. Klasifikasi Tanah dan Pedogenesis. Jakarta ID: Akademika Pressindo.

Jenny, H. 1941. Factors of Soil Formation. A System of Quantitative Pedology, Soil Science. Soil Science.

Meli, V., Sagiman, S., dan Gafur, S. 2018. Identifikasi Sifat Fisika Tanah Ultisols Kecamatan Nanga Tayap Kabupaten Ketapang. Perkebunan dan Lahan Tropika, 82, 80-90.

Mohr, E. C. J., Van Baren, F. A., dan Van Sehuylenborgh, J. 1975. Tropical Soils. Soil Science. https://doi.org/10.1097/00010694-197506000-00015

N., Suharta. 2007. Sifat dan karakteristik tanah dari batuan sedimen masam di Provinsi Kalimantan Barat serta implikasinya terhadap pengelolaan lahan. Jurnal Tanah dan Iklim, 25, 11-26.

Panjaitan, F., Jamilah, J., dan Damanik, M. 2015. Klasifikasi Tanah Berdasarkan Taksonomi Tanah 2014 Di Desa Sembahe Kecamatan Sibolangit. Jurnal Agroekoteknologi Universitas Sumatera Utara, 34, 106267. https://doi.org/10.32734/jaet.v3i4.11796

Rachim, D., dan Arifin, M. 2011. Dasar - dasar Klasifikasi Taksonomi Tanah. Pustaka Reka Cipta.

Rukmana, Y. Y., Zakaria, Z., Muslim, D., dan Seraphine, N. 2020. Korosifitas pada Tanah Lapukan Vulkanik Berdasarkan Nilai Tahanan Jenis Tanah di Kawasan UNPAD Jatinangor, Kabupaten Sumedang, Jawa Barat. Jurnal Geosaintek, 62, $77-86$. 
G. Herdiansyah, E. T. Sofyan, S. Bawana dan A. Herawati: Perkembangan Tanah dari Bahan Induk Vulkanik

Soil Survey Staff. 2014. Kunci Taksonomi Tanah. In edisi ketiga, 2015. . 2014. Soil Survey Field and Laboratory Methods Manual. USDANRCS Web Soil Survey Web Soil Survey Investigations. https://doi.org/10.13140/ RG.2.1.3803.8889 